\title{
EFISIENSI TEKNIS USAHATANI KENTANG DI KABUPATEN GOWA SULAWESI SELATAN
}

\author{
Ahsanah Mukarromah Arifin1), Anna Fariyanti'2), dan Netti Tinaprilla ${ }^{3)}$ \\ 1)Program Magister Sains Agribisnis, Sekolah Pascasarjana, Institut Pertanian Bogor \\ 2,3) Departemen Agribisnis, Fakultas Ekonomi dan Manajemen, Institut Pertanian Bogor \\ Jl. Kamper Wing 4 Level 5 Kampus IPB Dramaga Bogor, Indonesia \\ e-mail: 1)tatang92@gmail.com
}

(Diterima 18 Juli 2019 / Revisi 9 Agustus 2019 / Disetujui 16 September 2019)

\begin{abstract}
One of the ways to increase production was increasing technical efficiency. The purpose of this research was to analyze technical efficiency and factors that affected technical efficiency in Tinggimoncong District, Gowa Regency, South Sulawesi. This research used purposive sampling with 50 potatoes farmers. This study used Data Envelopment Analysis (DEA) approach and Tobit regression for data analysis. The result of the study showed that there are 23 farmers of the respondents stated to be efficient or about 46 per cent of the total respondents studied. Factors that significantly influence the technical efficiency of potato farming were education and income outside of farming
\end{abstract}

Keywords: DEA, potato, technical efficiency, tobit regression

\begin{abstract}
ABSTRAK
Salah satu upaya peningkatan produksi dapat dilakukan dengan cara peningkatan efisiensi teknis. Tujuan penelitian ini yaitu untuk menganalisis efisiensi teknis serta faktor-faktor yang mempengaruhi efisiensi teknis di Kecamatan Tinggimoncong Kabupaten Gowa Sulawesi Selatan. Teknik pengambilan sampel pada penelitian ini yaitu purposive sampling dengan jumlah responden sebanyak 50 petani kentang. Analisis data yang digunakan dalam penelitian ini yaitu analisis dengan pendekatan Data Envelopment Analysis (DEA) dan regresi Tobit. Hasil penelitian menunjukkan bahwa sebanyak 23 orang petani responden dinyatakan efisien secara teknis atau sekitar 46 persen dari total responden yang diteliti. Faktor-faktor yang signifikan berpengaruh terhadap efisiensi teknis usahatani kentang di Kecamatan Tinggimoncong yaitu pendidikan dan pendapatan di luar usahatani.
\end{abstract}

Kata kunci: DEA, efisiensi teknis, kentang, regresi tobit

\section{PENDAHULUAN}

Konsumsi kentang pada tahun 2012 hingga tahun 2016 terus meningkat dengan rata-rata pertumbuhan sebesar 16 persen. Konsumsi kentang pada tahun 2012 adalah sebesar 1,5 kg kapita/ tahun lalu pada tahun 2016 meningkat menjadi 2,5 kg kapita/tahun (Kementerian Pertanian 2017). Peningkatan konsumsi sebaiknya juga harus disertai dengan pemenuhan kebutuhan konsumsi baik dari produksi dalam negeri ataupun impor.

Produksi kentang dari tahun 2012 hingga tahun 2016 cenderung mengalamai peningkatan dengan rata-rata pertumbuhan sebesar 3,14 persen pada tahun 2012 hingga tahun 2016 (Kementerian Pertanian 2017). Sementara itu, pertumbuhan impor kentang juga mengalami peningkatan. Pada tahun 2015 ke tahun 2016 tercatat bahwa volume impor kentang meningkat sebesar 4,6 persen (Kementerian Pertanian 2017). Melihat kondisi ini maka perlu untuk meningkatkan produksi kentang di berbagai wilayah Indonesia agar impor dapat dikurangi dan kebutuhan masyarakat dapat terpenuhi.

Daerah penghasil kentang di Indonesia berada di Pulau Sumatera, Jawa, dan Sulawesi. Produktivitas kentang di Pulau Jawa dan Sumatera berturut-turut adalah sebanyak 19,6 ton/ha dan 19,00 ton/ha pada tahun 2016. Rata-rata produktivitas kentang di Pulau Jawa dan Sumatera telah melebihi produktivitas nasional yang mencapai 18,25 ton/ha pada tahun 2016. Namun, berbeda dengan pulau Sulawesi yang pada tahun 2016 
produktivitas kentangnya hanya mencapai 11 ton/ha (Kementerian Pertanian 2017).

Sulawesi Selatan merupakan salah satu daerah di Pulau Sulawesi yang memiliki kontribusi sebanyak 45 persen terhadap produksi kentang di Pulau Sulawesi dengan Kabupaten Gowa sebagai sentra produksi. Rata-rata produktivitas kentang di Kabupaten Gowa pada tahun 2016 adalah 17,2 ton/ha (BPS 2017). Jumlah ini masih berada di bawah jumlah produktivitas nasional yang mencapai 18.25 ton/ha (Kementerian Pertanian 2017).

Produktivitas kentang di Kabupaten Gowa masih belum memenuhi target terjadi karena produktivitas antar petani bervariasi sehingga ada gap antara produktivitas yang seharusnya dihasilkan dengan produktivitas aktual. Perbedaan produktivitas ini diduga karena penggunaan jumlah faktor-faktor input seperti benih, pupuk, pestisida, dan tenaga kerja. Rekomendasi mengenai jumlah penggunaan input yang tepat oleh penyuluh tidak dijadikan sebagai acuan dalam kegiatan usahatani sehingga pada umumnya petani kentang di Kabupaten Gowa menggunakan input secara bervariasi sesuai kebiasaan berusahatani tiap petani. Oleh karena itu perlu adanya perbaikan penggunaan input agar produktivitas kentang dapat meningkat.

Peningkatan efisiensi teknis merupakan salah satu cara yang dapat dilakukan untuk meningkatkan produktivitas. Srinivas et al. (2012) dan Belete et al. (2016) juga mengemukakan bahwa petani dapat meningkatkan produktivitas dengan cara mewujudkan efisiensi teknis.

Selain faktor input seperti benih; pupuk; pestisida; dan tenaga kerja, ada pula faktor non input yang berpengaruh terhadap efisiensi seperti kemampuan manajerial petani. Setiap petani memiliki kemampuan yang berbeda dalam mengelola usahataninya dan hal ini dipengaruhi oleh keadaan sosial ekonomi petani. Berdasarkan hal ini Belete et al. (2016) mengemukakan bahwa faktor sosial ekonomi berpengaruh terhadap skor efisiensi teknis.

Berdasarkan uraian tersebut maka rumusan masalah penelitian ini yaitu:

1. Bagaimana tingkat efisiensi teknis kentang di Kabupaten Gowa?
2. Apa sajakah faktor-faktor yang mempengaruhi efisiensi teknis kentang di Kabupaten Gowa?

Adapun tujuan dari penelitian ini yaitu:

1. Menganalisis efisiensi teknis kentang di Kabupaten Gowa

2. Menganalisis faktor-faktor apa saja yang mempengaruhi efisiensi teknis kentang.

\section{METODE}

\section{PENGUMPULAN DATA DAN ANALISIS}

Penelitian ini dilakukan di Kecamatan Tinggimoncong Kabupaten Gowa Sulawesi Selatan. Penentuan daerah pada penelitian ini ditentukan secara purposive dengan pertimbangan bahwa lokasi penelitian merupakan salah satu sentra dan pengembangan produksi kentang di Kabupaten Gowa. Waktu pengumpulan data dilakukan pada bulan November 2017 sampai Januari 2018. Data utama dalam penelitian ini yaitu data primer dan sekunder. Data primer diperoleh melalui wawancara dengan petani dan pihak yang terkait dengan usahatani kentang yang berada di Kecamatan Tinggimoncong Kabupaten Gowa. Data sekunder juga di dapat dari BPS dan dinas-dinas terkait.

\section{METODE PENENTUAN SAMPEL}

Sampel dalam penelitian ini adalah petani kentang di Kecamatan Tinggimoncong Kabupaten Gowa Sulawesi Selatan. Penentuan lokasi dipilih secara purposive dengan pertimbangan bahwa Kecamatan Tinggimoncong merupakan daerah dengan kontribusi kentang terbesar di Kabupaten Gowa. Metode penentuan sampel menggunakan purposive sampling dimana penentuan sampel ditentukan berdasarkan kriteria tertentu yaitu petani kentang yang masih melakukan kegiatan usahatani kentang. Pada lokasi penelitian tidak terdapat sample frame sehingga jumlah populasi tidak dapat diketahui. Ramanathan (2003) mengemukakan bahwa jumlah sampel untuk analisis DEA sebaiknya dua atau tiga kali lebih besr dari jumlah input dan output yang digunakan. Cohen et al. (2007) juga menyatakan bahwa jumlah minimal sampel adalah sebanyak 30 . Selain itu, Aprina (2007) menggunakan sampel sebanyak 50 pada penelitiannya sehingga jumlah sampel dalam penelitian ini yaitu sebanyak 50 
orang petani kentang karena dianggap telah dapat memenuhi syarat untuk melakukan uji analisis data.

\section{METODE ANALISIS DATA}

Metode analisis data yang dilakukan pada penelitian ini dilakukan secara kuantitatif. Analisis kuantitatif dilakukan dengan pendekatan Data Envelopment Analysis (DEA) dan regresi Tobit. Data primer yang diperoleh dari lapang kemudian diolah dengan bantuan perangkat komputer seperti DEAP versi 2.1 dan STATA Software.

\section{Metode Data Envelopment Analysis (DEA)}

Analisis efisiensi teknis usahatani dalam penelitian ini menggunakan pendekatan model Data Envelopment Analysis (DEA). DEA merupakan alat evaluasi kerja suatu aktivitas yang menggunakan satu atau lebih macam input dan satu atau lebih macam output.

Unit yang dievaluasi dalam metode DEA yaitu decision making unit (DMU) atau unit pengambil keputusan. Skor efisiensi diperoleh melalui perbandingan input dan output pada DMU. Nilai efisiensi teknis pada penelitian ini yaitu sama dengan satu dan jika nilai efisiensi kurang dari satu maka usahatani relatif tidak efisien secara teknis.

Secara matematis, perhitungan efisiensi teknis dengan model variable return to scale (VRS) dituliskan sebagai berikut:

$$
\begin{array}{r}
\text { Min } \theta, \lambda \theta \\
\text { st }-y_{i}+Y \lambda \geq 0, \\
\theta_{x i}-X \lambda \geq 0, \\
N 1^{\prime} \lambda=1 \\
\lambda \geq 0
\end{array}
$$

Keterangan :

$\mathrm{N} 1{ }^{\prime} \lambda=1$ merupakan kendala konveksitas (Convexity)

Variabel output dalam penelitian ini yaitu produksi dan produktivitas kentang, sedangkan variabel input yang digunakan pada penelitian ini yaitu benih kentang, pupuk organik, pupuk kimia, pestisida, dan tenaga kerja.

\section{Model Regresi Tobit}

Faktor yang memengaruhi efisiensi teknis dalam penelitiain ini dianalisis dengan menggunakan regresi tobit. Model tobit menggunakan metode Maximum Likelihood Estimation (MLE). Regresi tobit variabel tidak bebas atau terikat (dependent) terbatas nilainya (Censored), sedangkan variabel bebas (Independent) tidak terbatas nilainya (non-censored). Semua variabel bebas dan terikat diukur dengan benar, tidak ada autokorelasi; tidak ada heteroskedastisitas; tidak ada multikolineatitas yang sempurna; dan model matematis yang digunakan merupakan model yang tepat (Gujarati dan Dawn 2009).

Faktor yang mempengaruhi efisiensi teknis dalam penelitian ini dianalisis dengan menggunakan regresi Tobit. Regresi Tobit adalah model regresi yang mengasumsikan bahwa hanya variabel bebas yang tidak terbatas nilainya sedangkan variabel tidak bebasnya terbatas nilainya. Dengan kata lain regresi Tobit menggunakan sensor pada variabel tidak bebas dalam perhitungannya. Alasan penggunaan sensor ini yaitu agar tidak menghasilkan estimasi parameter dengan nilai variabel tidak bebas di luar batas yang ditentukan. Nilai efisiensi teknis merupakan nilai sensor yang digunakan dalam penelitian ini yang nilainya terbatas antara 0,00 hingga 1,00.

Variabel faktor-faktor yang diduga berpengaruh terhadap efisiensi teknis berdasarkan berbagai studi terdahulu dan disesuaikan dengan kondisi di lokasi penelitian yaitu usia petani, pendidikan, pengalaman berusahatani, jumlah tanggungan keluarga, status kepemilikan lahan, pendapatan di luar usahatani, dan akses kredit. Model Tobit yang digunakan adalah sebagai berikut:

$\mathrm{TE}=\beta_{0}+\beta_{1} \mathrm{X}_{1}+\beta_{2} \mathrm{X}_{2}+\beta_{3} \mathrm{X}_{3}+\beta_{4} \mathrm{X}_{4}+\beta_{5} \mathrm{X}_{5}+\beta_{6} \mathrm{X}_{6}+$ $\beta_{7} \mathrm{X}_{7}+\varepsilon$

Keterangan:

$\mathrm{TE}=$ Skor efisiensi teknis (0-1)

$\mathrm{X}_{1}=$ Usia petani (tahun)

$\mathrm{X}_{2}=$ Pendidikan (tahun)

$\mathrm{X}_{3}=$ Pengalaman berusahatani kentang (tahun)

$\mathrm{X}_{4}=$ Jumlah tanggungan keluarga (jiwa)

$\mathrm{X}_{5}=$ Dummy status kepemilikan lahan (1=milik, $0=$ bukan milik) 
$\mathrm{X}_{6}=$ Dummy pendapatan di luar usahatani (1=ada, 0 =tidak ada)

$\mathrm{X}_{7}=$ Dummy akses kredit ( $1=$ ada, $0=$ tidak ada $)$

$\varepsilon=$ Galat

$\beta=$ Parameter yang diestimasi

\section{HASIL DAN PEMBAHASAN}

\section{EFISIENSI TEKNIS KENTANG DI KECAMATAN TINGGIMONCONG}

Data yang digunakan dalam penelitian ini merupakan data produksi kentang selama satu tahun yaitu pada tahun 2016. Variabel yang digunakan dalam penelitian ini yaitu variabel input seperti benih, pupuk kimia, pupuk organik, pestisida, dan tenaga kerja. Selain itu ada juga variabel output berupa produksi kentang dan produktivitas kentang.

Analisis efisiensi teknis yang dilakukan pada peneitian ini menggunakan pendekatan Data Envelopment Analysis (DEA) dengan asumsi yang berorientasi input dan menggunakan model variable return to scale (VRS). Petani yang dapat dikatakan sudah efisien secara teknis yaitu petani yang memiliki nilai efisiensi teknis sebesar 1.000, sedangkan petani yang memiliki nilai efisiensi teknis di bawah nilai 1.000 tidak dapat dikatakan efisien secara teknis. Hasil perhitungan efisiensi teknis dapat dilihat lebih jelasnya pada Tabel 1.

Tabel 1 menunjukkan bahwa berdasarkan hasil perhitungan DEA dengan asumsi Variable Return to Scale Technical Efficiency terdapat 23 petani (46 persen) yang efisien secara teknis dan 27 petani (54 persen) yang belum efisien secara teknis. Rata-rata nilai efisiensi teknis petani sampel kentang di Kabupaten Gowa 0,842 (84,2 persen). Hasil ini menunjukkan bahwa sebagian besar petani sampel masih dapat meningkatkan nilai efisiensi seperti petani yang telah efisien secara teknis $(\mathrm{TE}=1)$. Perlunya peningkatan efisiensi teknis juga ditemukan pada penelitian Karimov (2013) mengenai efisiensi teknis kentang dan melon di Uzbekistan. Persentase petani kentang yang memiliki nilai efisiensi teknis sama dengan satu yaitu sebanyak 43,4 persen. Artinya sebagian besar petani masih perlu meningkatkan nilai efisiensi teknis. Lubis et al. (2014) pada penelitiannya juga menunjukkan bahwa rata-rata nilai efisiensi teknis dilihat dari variable return to scale adalah sebesar 78,8 persen. Artinya petani masih memungkinkan untuk meningkatkan efisiensi teknis sebesar 21,2 persen.

Shahnavazi (2018) menemuan hasil yang berbeda dimana pada penelitiannya mengenai efisiensi teknis kentang di Iran efisiensi teknis rata-rata di 22 provinsi yaitu 0.98. Hal ini menunjukkan bahwa penggunaan input seperti benih, pupuk kandang, herbisida, fungisida, insektisida, fosfat, nitrogen, kalium, dan tenaga kerja telah efisien secara teknis. Pahlavan et al. (2011) juga menemukan bahwa dari 27 petani responden yang diteliti terdapat 15 petani yang memiliki skor efisiensi sama dengan satu dan dinyatakan efisien secara teknis sementara 12 lainnya memiliki nilai skor efisiensi kurang dari satu dan dinyatakan belum efisien secara teknis atau sekitar 55,5 persen dinyatakan telah efisien secara teknis.

Efisiensi teknis merupakan kemampuan untuk mengurangi pemborosan dengan memaksimalkan jumlah output dan meminimalkan penggunaan input. Petani dapat meningkatkan jumlah output dengan mengimplementasikan Good Agricultural Practices (GAP) yang baik dan benar termasuk penggunaan bibit unggul dan input yang sesuai anjuran.

Tabel 1. Nilai Efisiensi Teknis Petani Kentang di Kabupaten Gowa

\begin{tabular}{lc}
\hline \multicolumn{1}{c}{ Keterangan } & VRSTE \\
\hline Nilai rata-rata (Mean) & 0,842 \\
Nilai efisiensi maksimum & 1,000 \\
Nilai efisiensi minimum & 0,421 \\
Total petani dengan nilai efisiensi sama dengan satu & 23 \\
Total petani dengan nilai efisiensi kurang dari satu & 27 \\
\hline
\end{tabular}

Sumber: Hasil analisis DEA, 2019 
Input Berlebih (Input Slack) Petani Responden Analisis efisiensi menggunakan DEA memungkinkan memperoleh hasil yang tidak efisien pada beberapa DMU. Slack merupakan tingkat inefisiensi pada DMU yang tidak efisien. Penggunaan input yang tidak efisien pada DMU disebut sebagai input slack. Nilai input slack lebih jelasnya dapat dilihat pada Tabel 2.

Benih merupakan salah satu input yang memiliki rata-rata penggunaan input slack yang cukup banyak yaitu sekitar 94,403 kg. Nilai ini mengindikasikan bahwa ada beberapa petani yang menggunakan benih berlebih dalam kegiatan usahatani kentang. Penggunaan input berlbih pada kegiatan usahatani kentang yang dilakukan oleh petani responden di Kecamatan Tinggimoncong diduga disebabkan oleh kebiasaan petani dalam melakukan kegiatan usahataninya hanya berdasarkan pengalaman saja. Setiap petani memiliki cara yang berbeda-beda dalam melakukan kegiatan usahatani kentang. Karimov (2013) juga menemukan bahwa benih merupakan input yang paling tidak efisien digunakan oleh petani. Temuan mengenai kesenjangan penggunaan benih juga terjadi pada penelitian Shahnavazi (2018) yang menemukan bahwa kesenjangan terbesar yaitu benih dengan penggunaan berlebih sebesar 850,3 kg.

Pupuk kimia dan pupuk organik juga memiliki input slack yang besar. Hal ini disebabkan karena banyak petani yang menganggap bahwa tingginya pupuk yang digunakan dapat meningkatkan jumlah produksi. Penggunaan pupuk kimia juga cukup besar dapat dilihat dari input slacknya. Petani rata-rata harus mengurangi pupuk kimia sebesar 208,260 kg dan 3.275,345 kg untuk pupuk organik. Raheli et al. (2017) mengemukakan bahwa pupuk kimia merupakan salah satu input yang menyebabkan perbedaan yang nyata antara petani yang efisien dengan petani yang tidak efisien.

Pestisida cair merupakan input produksi yang memiliki nilai slack terbesar yaitu $6.321,462$. Sedangkan pupuk kimia merupakan faktor input yang memiliki input slack dengan total petani terbanyak yaitu sebanyak 21 petani (42 persen) dari total 50 responden yang diteliti. Pestisida cair merupakan faktor input yang paling banyak digunakan petani secara berlebihan. Ratarata input slack untuk penggunaan pestisida cair adalah sebesar 6.321,462 ml. Berlebihnya penggunaan pestisida diduga terjadi karena kegiatan usahatani kentang merupakan kegiatan usahatani yang rentan terserang hama dan penyakit. Skevas et al. (2014) menyatakan bahwa pupuk dan pestisida merupakan input yang memiliki peran penting dalam produksi tanaman dan berpengaruh secara signifikan.

Nilai rata-rata input slack pestisida padat dan tenaga kerja secara berturut-turut yaitu 9,306 dan 11,482. Penggunaan tenaga kerja petani responden di Kecamatan Tinggimoncong rata-rata menggunakan tenaga kerja di luar keluarga. Namun untuk beberapa petani responden, banyak juga ditemukan sistem gotong royong sehingga jika ada petani yang membutuhkan tenaga lebih untuk kegiatan usahataninya maka petani lain akan membantu, begitu pula berlaku pada petani yang lainnya. Hal ini dapat membantu petani dalam mengurangi biaya pengeluaran untuk tenaga kerja. Selain sistem gotong royong, ada pula petani yang menetapkan sistem bagi hasil sehingga petani responden akan memberikan sepenuhnya kegiatan usahataninya kepada tenaga kerjanya.

Tabel 2. Nilai Input Slack Rata-rata Petani Responden di Kabupaten Gowa

\begin{tabular}{|c|c|c|c|}
\hline Variabel & $\begin{array}{c}\text { Rata-rata Nilai } \\
\text { Slack }\end{array}$ & $\begin{array}{c}\text { Jumlah } \\
\text { Responden }\end{array}$ & $\begin{array}{l}\text { Persentase } \\
\text { Responden }\end{array}$ \\
\hline Benih (kg) & 94,403 & 15 & 30 \\
\hline Pupuk Kimia (kg) & 208,260 & 21 & 42 \\
\hline Pupuk Organik (kg) & $3.275,345$ & 16 & 32 \\
\hline Pestisida Padat (kg) & 9,306 & 16 & 32 \\
\hline Pestisida Cair (ml) & $6.321,462$ & 10 & 20 \\
\hline Tenaga Kerja (HOK) & 11,482 & 11 & 22 \\
\hline
\end{tabular}

Sumber: Hasil analisis DEA, 2019 
Pestisida cair merupakan jenis input yang memiliki rata-rata jumlah slack yang terbesar dibandingkan kelima jenis input yang lain dengan rata-rata nilai slack yaitu $6.321,462 \mathrm{ml}$ dengan jumlah 10 responden (20 persen) dari total 50 responden yang diteliti. Sedangkan jenis input slack dengan jumlah responden terbanyak adalah pupuk kimia dengan total responden sebanyak 21 orang (42 persen) dari jumlah responden yang diteliti.

Petani dapat meningkatkan efisiensi dengan mengurangi jumlah penggunaan input. Hal ini sesuai dengan penelitian yang dilakukan Shahnavazi (2018) yang menemukan bahwa ratarata penggunaan benih, pupuk kandang, herbisida, fungisida, nitrogen, tenaga kerja, dan air melebihi penggunaan optimal. Selain itu Mardani dan Salarpour (2015) mengemukakan bahwa penggunaan pupuk, pestisida dan mesin yang ditargetkan dilakukan dapat meningkatkan efisiensi produksi kentang.

\section{FAKTOR-FAKTOR YANG MEMPENGARUHI EFISIENSI TEKNIS USAHATANI KENTANG DI KECAMATAN TINGGIMONCONG}

Beberapa variabel sosial ekonomi yang digunakan dalam regresi Tobit pada penelitian ini yaitu usia (tahun), pendidikan (tahun), pengalaman berusahatani kentang (tahun), status kepemilikan lahan (dummy), pendapatan di luar usahatani (dummy), dan akses kredit (dummy). Karakteristik petani responden di Kecamatan Tinggimoncong rata-rata memiliki usia 44 tahun, tingkat pendidikan 8 tahun, pengalaman berusahatani 21 tahun, dan jumlah tanggungan keluarga rata-rata 4 jiwa. Selain itu ada 20 petani yang memiliki pendapatan lain di luar usahatani, 44 petani yang memiliki lahan milik sendiri, serta ada pula 11 petani yang memiliki akses terhadap kredit untuk membantu kegiatan usahatani kentangnya.

Sebelum memutuskan apakah model yang digunakan sudah tepat dalam pendugaan maka perlu dilakukan pengujian model. Pengujian model ini dilakukan dengan uji normalitas dan melihat nilai Akaike Information Criterion (AIC). Uji normalitas yang digunakan pada penelitian ini adalah uji normalitas Shapiro Wilk. Berdasarkan hasil perhitungan menggunakan softwere STATA diperoleh nilai prob $>$ z yaitu sebesar 0,382 . Nilai ini lebih besar dari 0,05 sehingga dapat disimpulkan bahwa data berdistribusi normal. Selanjutnya untuk uji Akaike Information Criterion (AIC) diperoleh nilai sebesar 57,303.

\section{Hasil Pendugaan Regresi Tobit}

Berdasarkan analisis dengan menggunakan regresi Tobit, diperoleh hasil yaitu pendidikan dan pendapatan di luar usahatani berpengaruh secara signifikan terhadap efisiensi teknis. Faktor-faktor yang berpengaruh terhadap efisiensi teknis untuk lebih jelasnya dapat dilihat pada Tabel 3.

Hasil regresi Tobit pada Tabel 3 menunjukkan bahwa usia berpengaruh negatif terhadap efisiensi teknis usahatani kentang. Usia petani akan berpengaruh terhadap kinerja petani sehingga semakin bertambah usia petani maka akan mengurangi tingkat efisiensi teknis petani dalam menjalankan usahataninya. Amoah et al. (2014) dan Akamin et al. (2017) juga menemukan bahwa usia berpengaruh negatif terhadap efisiensi teknis. Hal ini sejalan dengan penelitian Khan

\section{Tabel 3. Hasil Regresi Tobit Faktor yang Mempengaruhi Efisiensi Teknis Usahatani Kentang} di Kabupaten Gowa

\begin{tabular}{lrc}
\hline \multicolumn{1}{c}{ Variabel } & Koefisien & Probabilitas (P>|t|t) \\
\hline Usia (tahun) & -0.0060 & 0.349 \\
Pendidikan (tahun) & $0.0190^{* *}$ & 0.084 \\
Pengalaman berusahatani kentang (tahun) & 0.0020 & 0.714 \\
Jumlah tanggungan keluarga (jiwa) & 0.0224 & 0.575 \\
Status kepemilikan lahan (Dummy) & -0.1412 & 0.377 \\
Pendapatan di luar usahatani (Dummy) & $-0.1562^{*}$ & 0.101 \\
Akses kredit (Dummy) & -0.0983 & 0.363 \\
\hline
\end{tabular}

Sumber: Hasil analisis regresi Tobit, 2019

Keterangan : ** Signifikan pada taraf $10 \%$

* Signifikan pada taraf $15 \%$ 
dan Saeed (2011) yang menyatakan bahwa usia yang lebih muda lebih efisien dengan petani yang memiliki usia lebih tua.

Pendidikan memiliki pengaruh positif dan signifikan terhadap efisiensi teknis. Petani yang memiliki tingkat pendidikan yang lebih tinggi memiliki jaringan yang lebih luas sehingga akses informasi yang diperoleh bisa lebih luas dan lebih cepat dibandingkan dengan petani yang memiliki tingkat pendidikan yang lebih rendah. Akses informasi yang lebih luas dan cepat dapat membantu petani memperoleh informasi mengenai teknologi, informasi penggunaan input yang tepat, serta pengetahuan mengenai teknik budidaya yang dapat membantu petani dalam mengelola usahataninya. Beberapa penelitian yang dilakukan oleh Amarasinghe dan Weerahewa (2001), Donkoh et al. (2013), Piya et al. (2012), dan Mapemba et al. (2013) mengemukakan bahwa pendidikan merupakan faktor yang berpengaruh positif terhadap efisiensi teknis usahatani. Pendidikan yang lebih tinggi dianggap mampu meningkatkan kemampuan manajerial petani dan membantu petani dalam mengambil keputusan.

Pendidikan memiliki pengaruh positif dan signifikan terhadap efisiensi teknis. Petani yang memiliki tingkat pendidikan yang lebih tinggi memiliki jaringan yang lebih luas sehingga akses informasi yang diperoleh bisa lebih luas dan lebih cepat dibandingkan dengan petani yang memiliki tingkat pendidikan yang lebih rendah. Akses informasi yang lebih luas dan cepat dapat membantu petani memperoleh informasi mengenai teknologi, informasi penggunaan input yang tepat, serta pengetahuan mengenai teknik budidaya yang dapat membantu petani dalam mengelola usahataninya. Beberapa penelitian yang dilakukan oleh Amarasinghe dan Weerahewa (2001), Donkoh et al. (2013), Piya et al. (2012), dan Mapemba et al. (2013) mengemukakan bahwa pendidikan merupakan faktor yang berpengaruh positif terhadap efisiensi teknis usahatani. Pendidikan yang lebih tinggi dianggap mampu meningkatkan kemampuan manajerial petani dan membantu petani dalam mengambil keputusan.

Pengalaman berusahatani juga memiliki pengaruh positif terhadap efisiensi teknis usahatani. Petani yang memiliki pengalaman berusaha- tani yang masih rendah akan cenderung lebih sering melakukan kesalahan dalam kegiatan budidaya sehingga jumlah produksi yang dihasilkan belum optimal. Petani dengan tingkat pengalaman yang masih rendah juga akan cenderung menggunakan kegiatan usahataninya sebagai ajang coba-coba dengan meminta nasihat atau saran dari petani lain yang sudah lebih berpengalaman. Maganga (2012) dan Hussain et al. (2014) juga mengemukakan bahwa pengalaman berusahatani memiliki pengaruh yang positif terhadap efisiensi teknis usahatani. Hal ini dikarenakan pengalaman berusahatani dapat membantu petani dalam pengambilan keputusan. Petani yang memiliki pengalaman berusahatani yang lebih lama dapat mengambil keputusan yang lebih baik karena telah belajar dari pengalaman kegagalan yang pernah terjadi.

Faktor jumlah anggota keluarga mempunyai pengaruh yang positif terhadap efisiensi teknis usahatani kentang walaupun tidak signifikan. Rata-rata jumlah tanggungan keluarga yang berada di Kecamatan Tinggimoncong yaitu empat orang dengan rata-rata minimal terdapat dua anggota keluarga yang dapat membantu dalam kegiatan usahatani sehingga tenaga kerja dapat berasal dari dalam keluarga dan membantu memperkecil biaya produksi. Nwaru et al. (2011) dan Mapemba et al. (2013) juga mengungkapkan bahwa jumlah anggota keluarga yang besar dapat mengatasi kendala tenaga kerja yang dihadapi oleh petani terutama di pedesaan yang lebih mengandalkan anggota keluarga sebagai tenaga kerja daripada mempekerjakan orang lain.

Status kepemilikan lahan berpengaruh negatif terhadap efisiensi teknis usahatani. Petani yang memiliki lahan milik sendiri berpengaruh mengurangi nilai efisiensi teknis pada kegiatan usahataninya. Terdapat 44 petani responden yang merupakan petani dengan status kepemilikan lahan milik sendiri atau sekitar 88 persen dari total responden. Banyak dari responden yang memilih untuk menyerahkan urusan budidaya ke tenaga kerjanya saja dan hanya mengawasi kegiatan usahatani tenaga kerjanya dan menyerahkan urusan budidaya kepada tenaga kerja yang mereka percaya. Hal ini dapat meningkatkan risiko kelalaian tenaga kerja dalam penggunaan input sehingga dapat memperbesar risiko 
kegagalan dan menjadikan kegiatan usahatani tidak efisien. Fauziyah (2010) dan Suharyanto et al. (2013) juga mengemukakan bahwa status kepemilikan lahan berpengaruh negatif terhadap efisiensi teknis usahatani. Selain itu, Tinaprilla (2012) juga mengemukakan bahwa petani yang memiliki lahan dengan status milik sendiri cenderung lebih lalai dalam mengelola usahataninya.

Pendapatan di luar usahatani juga berpengaruh negatif dan signifikan terhadap efisiensi teknis. Petani yang memiliki pendapatan di luar usahatani dapat memperoleh tambahan modal namun jika tidak dikelola dengan baik maka tidak akan berpengaruh terhadap efisiensi teknis usahatani. Selain itu petani yang memiliki pendapatan di luar usahatani akan tidak fokus mengelola usahataninya sehingga dapat menurunkan efisiensi. Fauziyah (2010) juga menemukan bahwa pendapat di luar usahatani dapat berpengaruh negatif terhadap efisiensi teknis. Namun, Khotimah dan Nurmalina (2012) mengemukakan bahwa sumber pendapatan lain dapat berpengaruh positif terhadap efisiensi teknis.

Akses terhadap kredit merupakan salah satu faktor yang berpengaruh terhadap ketidakefisienan dalam berusahatani sayuran kentang. Hal ini disebabkan karena kebanyakan petani kentang di Kecamatan Tinggimoncong tidak tertarik melakukan pinjaman dalam bentuk kredit dan lebih memilih modal sendiri atau pinjaman dari keluarga. Hasil pendugaan yang dilakukan oleh Nahraeni et al. (2012) dan Dube et al. (2018) juga menunjukkan bahwa adanya akses kredit dapat berpengaruh negatif terhadap efisiensi teknis usahatani kentang.

\section{SIMPULAN DAN SARAN}

\section{SIMPULAN}

1. Tingkat efisiensi teknis petani sampel di Kabupaten Gowa adalah sebesar 0,842 (84,2 persen) dengan 46 persen petani kentang sudah efisien secara teknis.

2. Faktor-faktor yang signifikan berpengaruh terhadap efisiensi teknis usahatani kentang di Kecamatan Tinggimoncong Kabupaten Gowa yaitu pendidikan dan pendapatan di luar usahatani.

\section{SARAN}

1. Petani kentang di Kecamatan Tinggimoncong Kabupaten Gowa dapat meningkatkan nilai efisiensi usahataninya dengan mengurangi jumlah penggunaan input yang berlebih terutama pada penggunaan, pupuk, benih, dan pestisida.

2. Sosialisasi mengenai pentingnya penggunaan input yang tepat juga perlu dilakukan melalui peran para penyuluh.

\section{DAFTAR PUSTAKA}

Akamin A, Bidogeza JC, N JRM, Afari SV. 2017. Journal of Integrative Agriculture. 16(8):1865-1873.

Amarasinghe STC, Weerahewa J. 2001. An Assessment to Technical Efficiency of Potato Production. Tropical Agriculturan Research 13:292-300

Amoah ST, Debrah IA, Abubakari R. 2014. Technical efficiency of vegetable farmer in Peri-Urban Ghana influence and effects of resource inequalities. American Journal of Agriculture and Forestry. 2(3):79-87.

Aprina N. 2017. Analisis risiko produksi petani padi di daerah aliran sungai Bengawan Solo, Kapupaten Bojonegoro Provinsi Jawa Timur. [tesis]. Bogor (ID): Institut Pertanian Bogor

Belete A, Setuno MP, Laurie SM, Senyolo MP. 2016. A Stocastic Frontier Approach to Technical Efficiency and Marketing of Orange Fleshed Sweet Potato (OFSP) at Farm Level: A Case Study of Kwazulu-Natal Province, South Africa. J Hum Ecol. 53(3):257-265.

[BPS] Badan Pusat Statistik. 2017. Kabupaten Gowa dalam Angka. (ID): Gowa

Brazdik F. 2006. Non Parametric Analysis of Technical Efficiency: Factors Affecting Efficiency of West Java Farms. [discussion paper]. Prague (CZ): Economics Institue, Academy of Scieces of the Czezh Republic.

Cohen L, Manion L, Morrison K. 2007. Research methods in education sixth edition. New York (NY): Routledge taylor and francis Group 
Donkoh SA, Tachega M, Amowine N. 2013. Estimating Technical Efficiency of Tomato Production in Northern Ghana. American Journal of Experimental Agriculture. 3(1):5675.

Dube AK, Ozkan B, Ayele A, Idahe D, Aliye A. 2018. Technical efficiency and profitability of potato production by smallholder farmers: The case of Dinsho District, Bale Zone of Ethiopia. Journal of Development and Agricultural Economics. 10(7):225-235.

Fauziyah E. 2010. Analisis efisiensi teknis usahatani tembakau (Suatu kajian dengan menggunakan fungsi produksi frontier stokhastik). EMBRYO. 7(1):1-7.

Gujarati ND, Dawn CP. 2009. Basic Econometrics Fifth Edition. New York (NY): The McGrawHill Companies.

Hussain N. Ali S, Miraj N, Sajjad M. 2014. An estimation of technical efficiency of garlic production in Khyber Pakhtunkwa Pakistan. International Journal of Food and Agricultural Economics. 2(2):169-178.

Karimov A. 2013. Production Efficiency of Potato and Melon Growing Farms in Uzbekistan: A two stage Double Boostrap Data Envelopment Analysis. Journal Agriculture. 3:503-5015.

2013. Economic ineficiency and shadow price of inputs: The case of vegetable growing farms in Uzbekistan. Journal Precedia Economics and Finance. 5:403-412.

Kementerian Pertanian. 2017. Statistik Pertanian 2017. (ID): Jakarta

2017. Basis data konsumsi pangan [Internet]. [diunduh 2019 Juli 01]. Tersedia pada:

http://aplikasi2.pertanian.go.id/konsumsi2 017/konsumsi/kapita_per_tahun

Khan H, Saeed I. 2011. Measurement of technical, allocative and economic efficiency of tomato farms in northern Pakistan. Journal of Agricultural Science and Technology. 2(10):1080.

Khotimah H. Nurmalina R. 2012. Pendapatan dan efisiensi teknis usahatani ubi jalar di Jawa
Barat : pendekatan stochastic frontier. Jurnal Forum Agribisnis. 2(2):141-160

Lubis RRB, Daryanto A, Tambunan M, Rachman HPS. 2014. Analisis Efisiensi Teknis Produksi Nanas: Studi Kasus di Kabupaten Subang Jawa Barat. Jurnal Agro Ekonomi 32(2):91106.

Maganga AM. 2012. Technicl Efficiency and its Determinants in Irish Potato Production: Evidence from Dedza District, Central Malawi. American-Eurassian J. Agric and Environ. Sci. 12(2):192-197.

Mapemba LD, Assa MM, Mango N. 2013. Farm Household Production Efficiency in Southern Malawi: An Efficiency Decomposition Approach. Journal of Economics and Sustainable Development. 4(3): 236-246.

Mardani M, Salarpour M. 2015. Measuring technical efficiency of potato production in Iran using robust data envelopment analysis. Information Processing in Agriculture 2:6-14.

Nahraeni V, Hartoyo S, Syaukat Y, Kuntjoro. 2012. Pengaruh Kemiringan Lahan dan Sistem Konservasi Terhadap Efisiensi Usahatani Kentang Dataran Tinggi. Jurnal Pertanian. 3(1):1-12.

Nwaru JC, Okoye BC, Ndukwu PC. 2011. Measurement and determinants of production efficiency among small-holder sweet potatoe (Ipomoea batatas) farmers inimo State Nigeria. European Journal of Scientific Research 59(3):307-317.

Pahlavan R, Omid M, Akram A. 2011. Energy use efficiency in greenhouse tomato production in Iran. Journal Energy. 36:6714-6719.

Piya S, Kiminami A, Yagi H. 2012. Comparing the technical efficiency of rice farms in urban and rural areas: A case study from Nepal. Trends in Agricultural Economics. 5(2):48-60.

Raheli H, Rezaei RM, Jadidi MR, Mobtaker HG. 2017. A two stage DEA model to evaluate sustainability and energy efficiency of tomato production. Journal Information Processing in Agriculture. 4:342-350.

Ramanathan R. 2003. An introduction to data envelopment analysis a tool for performance 
measurement. London (UK): Sage publication.

Shahnavazi A. 2018. Technical, Allocative, and Economic Efficiencies of Potato Production in Iran. International Journal of Farming and Allied Sciences. 7(3):73-77

Skevas T, Stefanou SE, Lansink AO. 2014. Pesticide use, environmental spillovers and efficiency: A DEA risk-adjusted efficiency approach applied to Dutch arable farming. Europan Journal of Operational Research. 237:658-664

Srinivas T, Risvi SJH, Aw-Hasan A, Manan AR, Kadian MS. 2012. Technical Efficiency of Seed Potato Farmers of Badakshan Province of Afganistan. Potato J. 39(2):118-127.

Suharyanto, Mulyo JH, Darwanto DH, Widodo S. 2013. Analisis Efisiensi Teknis Pengelolaan Tanaman Terpadu (PTT) Padi Sawah di Provinsi Bali. Jurnal SEPA. 9(2):219-230.

Tinaprilla N. 2012. Efisiensi Usahatani Padi Antar Wilayah Sentra Produksi di Indonesia: Pendekatan Stacastic Metafrontier Production Function. [disertasi]. Bogor (ID): Institut Pertanian Bogor. 